\title{
Tantalum-or Titanium-Catalyzed Peptide Synthesis
}

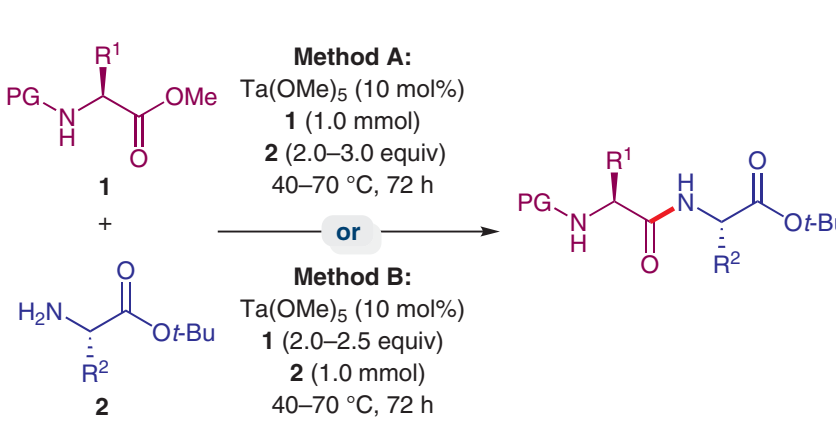

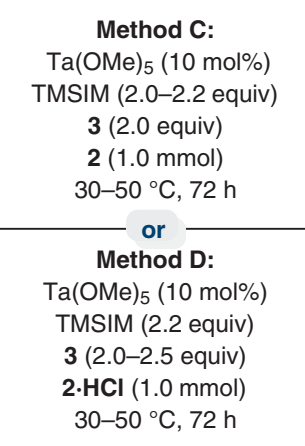

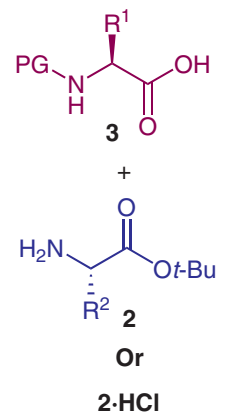

Selected examples
Category

Peptide Chemistry

\section{Key words}

tantalum catalysis

titanium catalysis

substrate-directed

reaction

\section{Synfact Month}

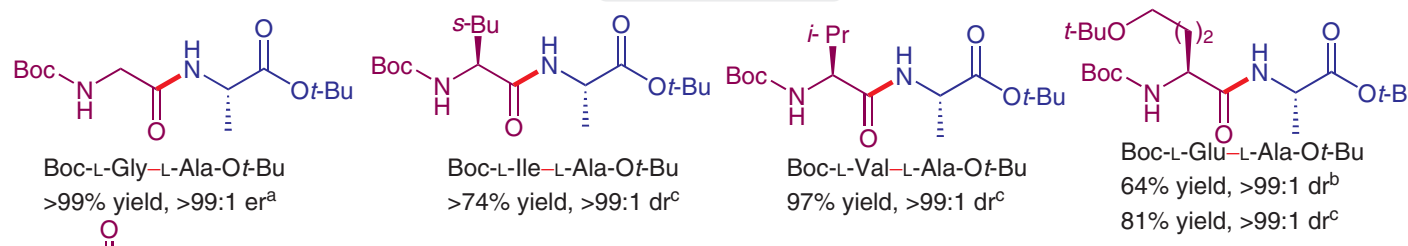<smiles>CCCCOC(=O)[C@H](C)NC(=O)[C@H](CC(=O)NC(C)(C)C)NC(=O)OCC</smiles>

Boc-L-Gln-L-Ala-Ot-Bu $59 \%$ yield, $>99: 1 d r^{d, e}$<smiles>CCCCC(NC(=O)C(C)NC(=O)OCc1ccccc1)C(=O)OC(C)(C)C</smiles>

Boc-L-Ala-L-lle-Ot-Bu $93 \%$ yield, $>99: 1 d r^{a}$<smiles>CCCOC(=O)[C@H](Cc1ccccc1)NC(=O)[C@H](C)NC(=O)OC(C)(C)C</smiles>

Boc-L-Ala-L-Phe-Ot-Bu $95 \%$ yield, >98:2 $\mathrm{dr}^{\mathrm{a}}$
Boc

Boc-L-Ala-L-Leu-Ot-Bu $95 \%$ yield, $>98: 2 d r^{a}$

\footnotetext{
PG-peptide-OH

Titanium-catalyzed peptide coupling reaction

(2.0 equiv)

$\mathrm{Ti}(\mathrm{O} i-\mathrm{Pr})_{4}(10 \mathrm{~mol} \%)$. TMSIM (2.2 equiv)
peptide-Ot-Bu
$40-50{ }^{\circ} \mathrm{C}, 36-72 \mathrm{~h}$
PG-peptide-peptide-Ot-Bu

Cbz-Gly-Gly-L-Phe-L-Leu-Ot-Bu Cbz-Gly-Gly-Gly-Gly-L-Ile-Ot-Bu

$72 \%$ yield, $\mathrm{dr}=94: 6$ (in DMSO) $99 \%$ yield, dr > 99:1, (2 mol\% Ti, in DMSO) $\quad 98 \%$ yield, dr $>99: 1,\left(\right.$ in $\left.\mathrm{CHCl}_{3}\right)$
}

a Prepared by following method A. ${ }^{b}$ Prepared by following method B. ${ }^{\mathrm{c}}$ Prepared by following method C.

d Prepared by following method D. ${ }^{e} 0.5 \mathrm{~mL} \mathrm{CHCl}{ }_{3}$ solvent used. TMSIM $=1$-(Trimethylsilyl)imidazole.

Significance: The development of elegant synthetic methodologies for peptide-bond formation is a highly demanding task in organic synthesis. A substrate-directed, Lewis acid-catalyzed, racemization-free amidation method has been developed to access various peptides.
Comment: The tantalum-catalyzed substrate-directed peptide-bond-formation reaction proceeds with various amino acids under solvent-free conditions and delivers peptides in high yields without racemization. This method further extends titanium-catalyzed oligopeptide synthesis. 